\title{
膀胱癌に対する経膀胱鏡的腔内照射治療
}

\author{
秋田大学医学部泌尿器科 (主任：土田正義教授) \\ 原田忠

\section{NEW TECHNIQUE OF TRANSCYSTOSCOPIC INTRACAVITARY IRRADIATION FOR CARCINOMA OF THE URINARY BLADDER}

\author{
Tadashi Harada \\ Department of Urology, Akita University School of Medicine, Akita \\ (Director: Prof. Seigi Tsuchida)
}

\begin{abstract}
A remote controlled transcystoscopic intracavitary after-loading unit has been introduced to irradiation therapy of bladder carcinoma. Using intense radiation therapy, a significant dose can be delivered to the tumor in a short period of time. Uning transcystoscopic intracavitary irradiation, we have treated fourteen patients with transitional cell carcinoma of the bladder. Nine patients initially showed a complete response, although within several months, 3 patients subsequently showed recurrence in a different part of the bladder. Utilizing this technique, technical difficulties and severe complications were not encountered. The preliminary results and actual technique of transcystoscopic intracavitary irradiation are reported.
\end{abstract}

要旨：Remote Afterloading System（RALS-20B）を用いた新しい経膀胱鏡的局所照射を紹介した. 14 例の膀胱癌患者に本治療を施行し，9例に CR を得た. しかしこのらち 3 例は数カ月以内に異所性再発を 認めた。

この方法により腫瘍局所に充分な線量を照射可能で副作用を軽減でき，治療術者への放射線被爆量を なくすことができる.

\section{1. 緒言}

膀胱癌に対する放射線治療は，浸潤した腫瘍に術前 処置として行なわれたり, 手術困難な症例に化学療法 などと併用して施行されることが多い。この場合, 照 射方法としては, 汪とんどが, テレコバルトやリニアッ クを用いて体外から照射するいわゆる外照射によって 行われている．膀胱腫瘍を外照射のみで根治的治療を 行う場合, 6,500 7,000 rad 以上の線量が必要である と考えられている11. しかし抗腫瘍効果を期待できる 線量を用いると, 腫瘍ばかりでなく, 隣接臓器に障害 を与えたり，全身的な副作用を発現することが多い2． そこで最近は，このような副作用をみることなく治療 効果を上げるために, 開創照射3)4) や膀朕内照射治療法 が試みられている。

腔内照射治療は, ${ }^{24} \mathrm{Na},{ }^{62} \mathrm{Br}$ などの放射性同位元素 を含んだ溶液を膀脱内に充満させたり ${ }^{5)}$ ，尿道から膀 胼内にバルンカテーテルを留置し, バルンを膨らませ, その中心部に Ra, Cs などの線源を留置し, 照射する方 法が報告されている67).
しかしこれらの治療法は手術操作が必要であった り，使用する放射性同位元素の放射活性が低いため， 照射に長時間を要し，その間，患者を治療棟に隔離管 理しなければならず，患者は日常生活が制限され精神 的にも大きな負担となる。また，この方法には施術者 や医療スタッフへの被爆の危険を少なからず伴ってい ることも欠点の一つである.

このような欠点を解決し，かつ腫湯部に充分量の放 射線を照射できる新しい方法として，私は遠隔操作式 後充填法を用いた経膀胱鏡的腔内照射法を考案し，そ の概要をすでに報告8)したが，今回14例の膀胱腫瘍に 対し本法で治療を試みたので, 短期間の観察であるが, その成績を報告する。

\section{2. 装置の概要および手技}

1）膀胼内照射用内視鏡の構造：今回試作した腔内 照射用膀胱鏡は, 外筒管の径が Fr. 24, 対物レンズの 視軸角 $5^{\circ}$, 視野角 $70^{\prime}$ の内視鏡で, 線源を誘導する直径 $3.5 \mathrm{~mm}$ のステンレス製 loadintg tube が通過できる applicator channel を設けてある.このため光学管は 
Fig. 1 Diagram of transcystoscopic intracavitary irradiation for carcinoma of the urinary bladder.

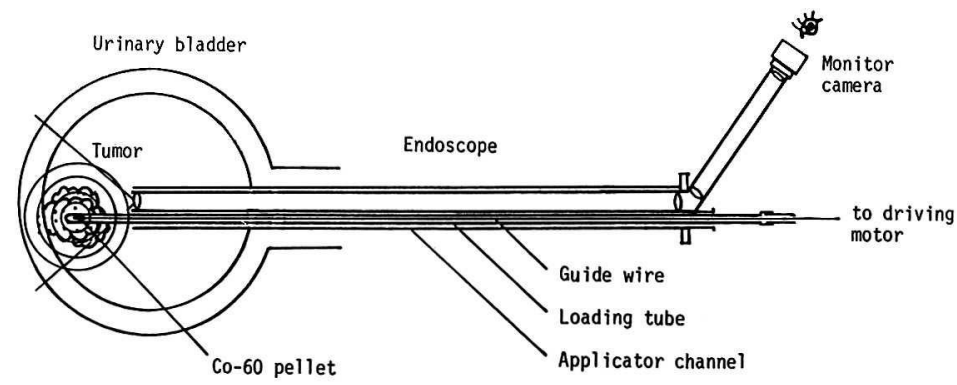

Fig. 2 A; photograph of a refracted cystoscope.

$\mathrm{B}$; Photograph of a suspending handle.
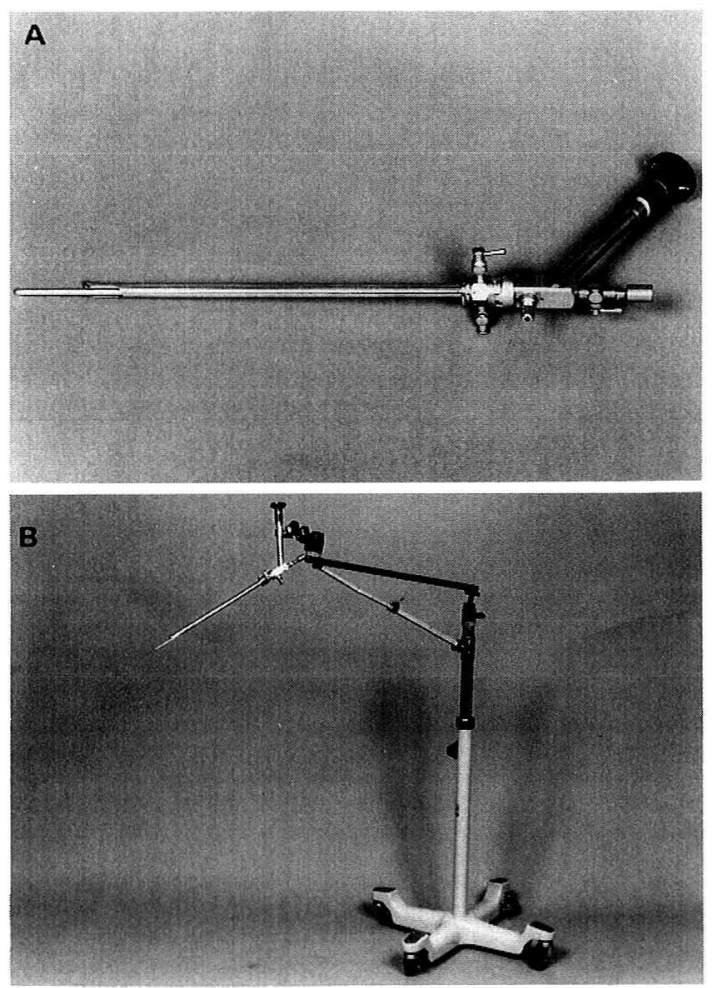

プリズムを使用し，手元で屈接しているのが特徵であ る(Fig. 1, 2).

2) 遠隔操綐式後充填装置および線源：線源の誘導 に使用した遠隔操縦式後充填装置 (Remote-controlled After-loading System)は島津製 RALSTRON 20B で ある. 本装置はFig. 3 に示したごとく移送用ワイヤー と連結した線源，それを格納する container，線源と目 的部位まで移送するための駆動モーターおよび線源移 送用軟性導管とから構成されている。そしてコント
Fig. 3 Diagram of an after-loading system, RALSTRON 20-B.

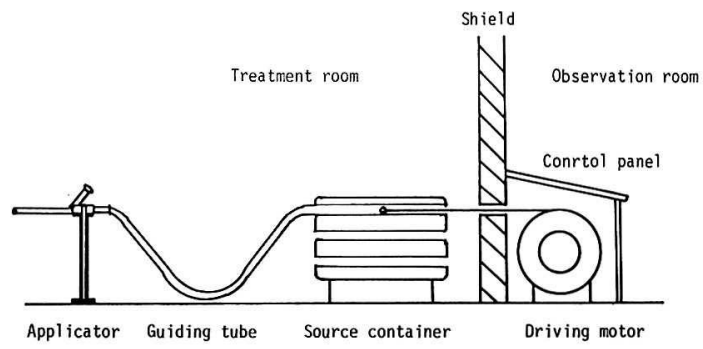

ロールパネルによって線源を予め loading tube のど この部位に停留させ, 何秒間照射を行からかを計画で きるようになっている.使用した線源は1Ci 执よび3Ci のCo-60ペレットでいずれも直径 $3 \mathrm{~mm}$, 長さ $16 \mathrm{~mm}$ の 円筒状のステンレススチールカプセルによって被覆さ れ，一端はワイヤーで駆動モーターと連結している。

3）膀胱腔内モニター装置：照射中, 照射線源の移動 がないように膀胱鏡を固定する支持機 (Fig. 2), 照射 中も膀脱内を観察できるようなビデオモニターシステ ム (武井製 $\mathrm{CCD}$ 内視鏡カメラ) 扣よびレ線撮影装置を 使用する。

4）治療室の構成：治療室および観察室はコンク リート壁によって遮閉されている, 治療室には, 膀脱 鏡用テーブルと，線源が格納された container および レ線撮影装置が配置されている。観察室には, コント ロールパネル拉よびレ線モニター, 膀胱腔内モニター システムが配置されている (Fig. 4).

5）照射方法：患者を膀胱鏡検査台に載石位で固定 する， $2 \%$ キシロカインゼリーで尿道粘膜麻酔を行 なった後, 膀胱鏡検查の要領で照射用膀悓鏡を膀胱内 に挿入する，滅菌蒸留水を注入しながら，膀腃内を観 察し，腫瘍の大きさ，位置，性状を確認する，次いで applicator channel から loading tube を插入し，先端 
Fig. 4 Diagram of the treatment suite.

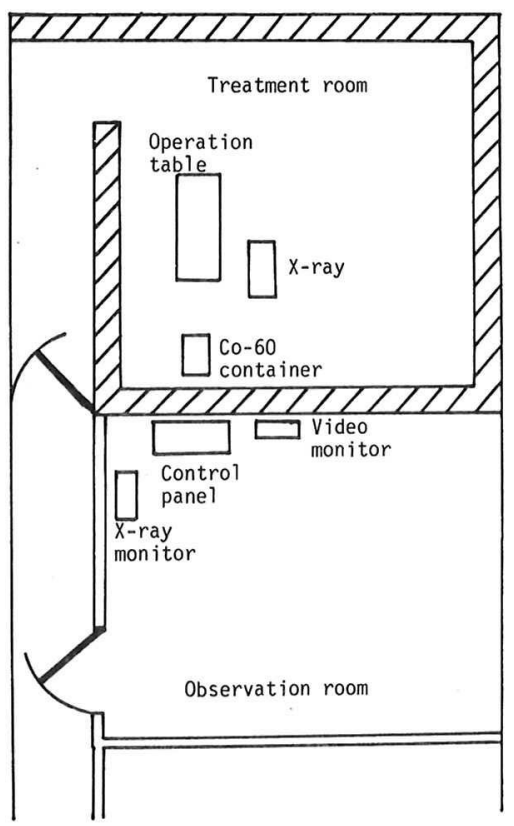

Fig. 5 Dose distribution curve obtained by corputer analysis using with $\mathrm{Co}-60$ of $3 \mathrm{Ci}$ activity, and for ten mimute duration of radiation.

(RAD)

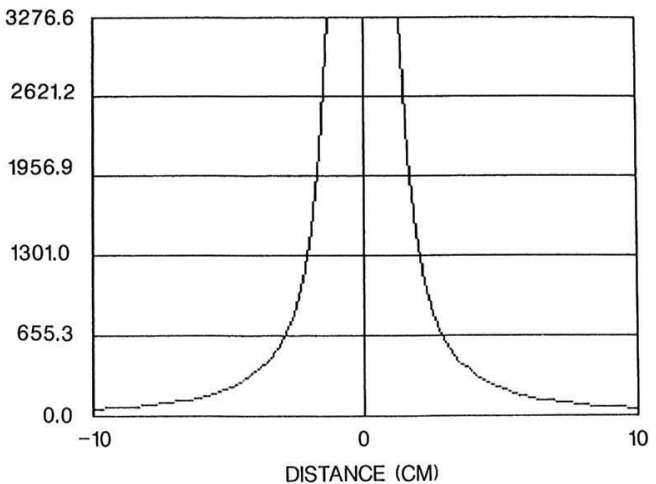

から $5 \mathrm{~mm}$ 手前の部位，すなわち誘導された線源が停留 する位置が腫瘍の中心部に当たるように密着させ，膀 胱鏡を固定用支持機に装着する，次に擬似線源を誘導 し， レ線モニターで線源が適当な部位に当っているか ぞうかを確認した後，1CiのCo-60ペレットを誘導す る軟性導管と loading tubeをポリエチレン性連結管 で結合する，膀胱鏡の接眼レンズに CCD カメラを装 置し，膀胱内を観察室からモニターできるようにすれ ば照射準備は完了する。

患者を治療室に残し，スタッフは観察室に移り，照
Fig. 6 Dose distribution obtained by computor analysis (Case No. 1). Intracavitary irradiation was repeated three times toward tumors in the bladder after the positioning the applicator tip to another lesion. Each peripheral tumor dose was estimated 1,280rad.

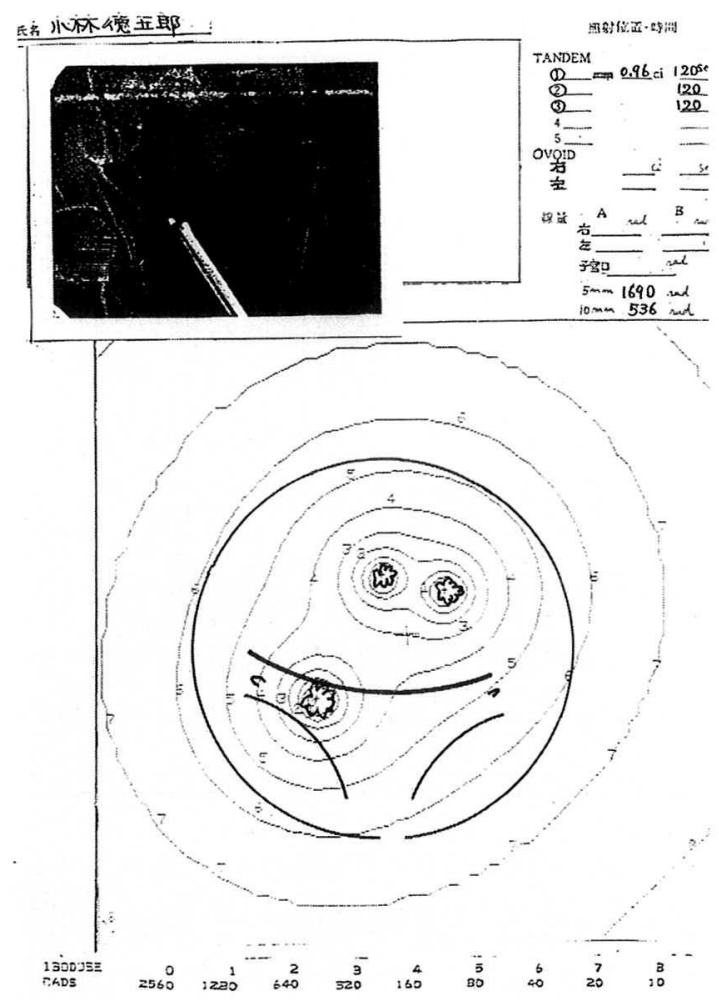

射を開始する。照射は通常 1 個の腫瘍に対して $1 \mathrm{Ci}$ の 線源で 1 〜 分間とし, 照射終了後レ線撮影を行なう. 腫瘍の大きさが直径 $2 \mathrm{~cm}$ を越兄るもの，あるいは多発 している腫瘍で相互の間隔が $1 \mathrm{~cm}$ 以上離れている場 合は, loading tube を必要な部位に移動し照射を繰り 返すが，その都度レ線撮影を行なう。この撮影された レ線フィルムは線量分布図作成に利用する。

6）線量計測法：今回使用した線源は非常に小さい ので点線源と考学ることができる，点線源周囲組織の 照射線量率はFig. 5 に示した通りで, 距離が離れるに 従い指数関数的に減少する。すなわち経膀胼鏡的局所 照射の場合腫瘍に対しての線量分布は，線源に密着し た部分な著しく高いのに対し，腫瘍の辺縁では低く なっている.腫瘍に対して一定の線量を照射するため, 腫瘍の大ささにかかわらず照射線源からも最も離れた 腫瘍辺縁部を tumor peripheral point（以下 P-point 
と略す）としてこの部分の線量を加算した值を tumor peripheral dose (以下 P-dose と略す) とし, 照射総線 量の Index とした。実際の線量測定は線量分布解析装 置 (CMS RTP-RELEASE 2，3）に線源の種類, 放射 活性, 照射時間とレ線写真から得られる線源の部位お よび P-pointを入力し, 算出した。腫瘍が大きかった り, 複数個発生している腫瘍に対しては, 線源を移動 しながら照射を繰り返すことになるが，それぞれの P-point, 照射時間を入力することによって線量分布図 を得ることができる（Fig. 6).

\section{3. 対}

1985年 4 月以降, 膀胱移行上皮癌と診断された患者 14例に対して, 経膀胱鏡的腔内照射治療を行った. 14 例中 8 例は過去に TUR を 1 回以上，あるいは膀胼部 分切除を受けてから再発を来した患者であった。 8 例 は多発性の腫瘍であり, このらち 4 例は, 筇層への浸 潤あるいは広範囲に腫瘍が及んでいて膀羘全摘出術の 適応も考えられた症例であった（Table 1). しかし全 例とも遠隔転移，所属リンパ節への浸潤は認められな かった. 照射治療は 1 週間毎に $1 \sim 5$ 回施行した.

本治療終了 $1 \sim 2$ 週間後に膀胱鏡, 生検および細胞 診を行い照射の抗腫瘍効果を判定した。 その後も 1 〜 3 カ月毎に検查を施行し, 経過観察を行った. 腫瘍 が膀胱鏡で全く消失した症例は complete response (CR)，50\%以上の縮小は partal response(PR), 50\% 未満の縮小あるいは变化の認められなかった例はno change（NC）と判定した.

\section{4. 結 果}

一過性の頻尿の他は支障なく14例に対し計49回の照 射治療を行なった. 1 回の治療に要する時間は約20分 であった。それぞれの患者の照射回数は膀胱鏡所見を 参考に $1 \sim 5$ 回平均 3.9 回施行された(Table 2). これ による腫瘍辺縁の放射線被爆線量 (P-dose) は2,950 〜9,650 (平均 4,231) radであった (Table 2). 治療 終了時に膀胱鏡で腫瘍が消失した症例は14例中10例 で，1例は著明に縮小したが，残る 3 例はほとんど変 化が認められなかった。消失した症例の中で反応の早 い症例は， 1 回の照射で 1 週間後には消失したが，大 半の症例は $3 \sim 5$ 回の照射で腫瘍は消失した. 生検で は膀脱鏡的に腫瘍の消失した 10 例中 8 例に悪性所見は 認められなくなった。 5 例は治療終了後の生検で依然 として悪性所見を認め，1例は判定不能であった。治 療後の細胞診では 8 例が陰性であったが, 腫瘍の消失 のみられなかった 4 例と, 膀胱鏡では腫瘍が消失した が生検で陰性化しなかった 2 例は細胞診でも陽性ある いは擬陽性であった (Table 2). 腫瘍の消失のみられ なかった 4 例，および膀脱鏡的に消失したが生検ある いは細胞診で陽性であった 2 例に対しては既に報告し たマイクロ波を用いて凝固治療を追加した99.

腫瘍の消失した 10 例のうち 3 例で治療後 $2 \sim 6$ カ月

Table 1 Patients

\begin{tabular}{|c|c|c|c|c|c|c|c|c|c|c|}
\hline \multirow{2}{*}{ No. } & \multirow{2}{*}{ Name } & \multirow{2}{*}{ Age } & \multirow{2}{*}{ Sex } & \multirow{2}{*}{ History (before) } & \multicolumn{6}{|c|}{ Tumor } \\
\hline & & & & & Growth pattern & Size $(\mathrm{cm})$ & Number & Stage & Histology & Grade \\
\hline 1 & T. K. & 69 & M & TUR & papillary & 1.5 & 3 & TaN0M0 & TCC & G1 \\
\hline 2 & R. K. & 60 & M & TUR $\times 2$ & papillary & 2.0 & 3 & TaN0M0 & TCC & G1 \\
\hline 3 & R. K. & 54 & M & $\begin{array}{l}\text { partial } \\
\text { cystectomy }\end{array}$ & papillary & 1.0 & 1 & $\begin{array}{l}\text { T2N0M0 } \\
\mathrm{T}\end{array}$ & TCC & $\mathrm{G} 2$ \\
\hline 4 & T. I. & 57 & $\mathrm{~F}$ & - & papillary & 6.0 & 4 & T1N0M0 & TCC & G2 \\
\hline 5 & N. S. & 82 & $\mathrm{~F}$ & - & papillary & 5.0 & 1 & T1N0M0 & TCC & G1 \\
\hline 6 & H. K. & 74 & $\mathrm{~F}$ & - & non-papillary & 1.0 & 1 & T1N0M0 & TCC & G3 \\
\hline 7 & M. O. & 70 & M & - & papillary & 2.5 & 3 & T2N0M0 & TCC & G3 \\
\hline 8 & K. A. & 64 & M & - & papillary & 1.0 & 1 & TaN0M0 & TCC & G2 \\
\hline 9 & K. K. & 72 & M & TUR & papillary & 0.5 & 1 & TaN0M0 & TCC & $\mathrm{G} 2$ \\
\hline 10 & K. S. & 58 & M & TUR & non-papillary & 1.0 & 3 & TaN0M0 & TCC & G2 \\
\hline 11 & G. I. & 79 & M & - & papillary & 1.0 & 2 & TaN0M0 & TCC & G1 \\
\hline 12 & T. A. & 52 & M & TUR $\times 2$ & papillary & 1.0 & 1 & TaN0M0 & TCC & G1 \\
\hline 13 & T. S. & 48 & $\begin{array}{l}\mathrm{M} \\
\mathrm{M}\end{array}$ & $\begin{array}{l}\text { partial } \\
\text { cystectomy } \\
\text { TUR ×5 }\end{array}$ & non-papillary & 2.0 & 3 & T1N0M0 & TCC & G3 \\
\hline 14 & I. S. & 82 & & - & papillary & 2.0 & 3 & T2N0M0 & TCC & $\mathrm{G} 1$ \\
\hline
\end{tabular}


Table 2 Clinical evaluation

\begin{tabular}{|c|c|c|c|c|c|c|}
\hline \multirow{2}{*}{ No } & \multicolumn{2}{|c|}{ Intracavitary irradiaation } & \multicolumn{3}{|c|}{ Examinations } & \multirow[b]{2}{*}{ Remarks } \\
\hline & Treatment & $\begin{array}{l}\text { Peripheral tumor } \\
\text { dose (rad) }\end{array}$ & Cystoscopy & Biopsy & Cytology & \\
\hline 1 & $\begin{array}{l}(1 \mathrm{Ci}, 60 \mathrm{sec}) \times 4 \\
(1 \mathrm{Ci}, 120 \mathrm{sec}) \times 2\end{array}$ & 4404 & NR & $(+)$ & $(+)$ & $\begin{array}{l}\text { additional MC } \\
\mathrm{HR} \text { at } 6 \text { and } 12 \mathrm{mo} .\end{array}$ \\
\hline 2 & $\begin{array}{l}(1 \mathrm{Ci}, 120 \mathrm{sec}) \times 4 \\
(1 \mathrm{Ci}, 120 \mathrm{sec}) \times 4\end{array}$ & 4250 & NR & $(+)$ & $(+)$ & additional MC \\
\hline 3 & $(1 \mathrm{Ci}, 120 \mathrm{sec}) \times 4$ & 4390 & PR & $(+)$ & $(+)$ & additional MC \\
\hline 4 & $(2.4 \mathrm{Ci}, 60 \mathrm{sec}) \times 5$ & 3600 & PR & $(+)$ & $(+)$ & additional $\mathrm{MC}$ \\
\hline 5 & $(2.4 \mathrm{Ci}, 60 \mathrm{sec}) \times 5$ & 4820 & CR & $(+)$ & $(+)$ & additional MC \\
\hline 6 & $\begin{array}{l}(1 \mathrm{Ci}, 60 \mathrm{sec}) \times 1 \\
(1 \mathrm{Ci}, 120 \mathrm{sec}) \times 2\end{array}$ & 3808 & $\mathrm{CR}$ & $( \pm)$ & $( \pm)$ & $\begin{array}{l}\text { additional MC } \\
\mathrm{HR} \text { at } 2 \text { and } 3 \text { mo. }\end{array}$ \\
\hline 7 & $(1 \mathrm{Ci}, 60 \mathrm{sec}) \times 2$ & 9820 & CR & $(-)$ & $(-)$ & $\mathrm{HR}$ at 3 and $5 \mathrm{mo}$. \\
\hline 8 & $(1 \mathrm{Ci}, 120 \mathrm{sec}) \times 5$ & 7692 & $\mathrm{CR}$ & $(-)$ & $(-)$ & $\mathrm{HR}$ at $12 \mathrm{mo}$ \\
\hline 9 & $(1 \mathrm{Ci}, 120 \mathrm{sec}) \times 1$ & 2560 & CR & $(-)$ & $(-)$ & NED 14 mo. \\
\hline 10 & $\begin{array}{l}(1 \mathrm{Ci}, 60 \mathrm{sec}) \times 1 \\
(1 \mathrm{Ci}, 120 \mathrm{sec}) \times 5\end{array}$ & 9651 & $\mathrm{CR}$ & $(-)$ & $(-)$ & NED 14 mo. \\
\hline 11 & $\begin{array}{l}(1 \mathrm{Ci}, 120 \mathrm{sec}) \times 3 \\
(1 \mathrm{Ci}, 120 \mathrm{sec}) \times 3\end{array}$ & 5160 & $\mathrm{CR}$ & $(-)$ & $(-)$ & NED $10 \mathrm{mo}$. \\
\hline 12 & $(1 \mathrm{Ci}, 120 \mathrm{sec}) \times 3$ & 4500 & $\mathrm{CR}$ & $(-)$ & $(-)$ & NED $10 \mathrm{mo}$. \\
\hline 13 & $\begin{array}{l}(1 \mathrm{Ci}, 120 \mathrm{sec}) \times 3 \\
(1 \mathrm{Ci}, 60 \mathrm{sec}) \times 3 \\
(1 \mathrm{Ci}, 60 \mathrm{sec}) \times 3\end{array}$ & 7800 & $\mathrm{CR}$ & $(-)$ & $(-)$ & NED 8 mo. \\
\hline 14 & $\begin{array}{l}(1 \mathrm{Ci}, 120 \mathrm{sec}) \times 3 \\
(1 \mathrm{Ci}, 120 \mathrm{sec}) \times 3 \\
(1 \mathrm{Ci}, 120 \mathrm{sec}) \times 3\end{array}$ & 4500 & CR & $(-)$ & $(-)$ & NED $8 \mathrm{mo}$. \\
\hline
\end{tabular}

peripheral tumor dose : caliculated irradiative dose at the margin of lesions.

CR : total disappearance of the tumor

PR : $50>$ percent of the malignant lesions

NR : no significant change

HR : heterotopic recurrence in the bladder

NED : no evidence of disease

MC : microwave coagulation

後に治療した部位とは別の膀胱粘膜に腫瘍の再発を認 めた。これらに対しては再度 $3 \sim 4$ 回の経膀胱鏡的腔 内照射治療を施行し, 治療後これらの腫瘍も消失した。 放射線照射回数あるいは照射線線量と腫場の消失との 間には明らかな関係は認められなかった。

治療に伴ら副作用および合併症を述べる，照射後一 過性の膀胱刺激症状を 4 例に認めたが，数日後には軽 快した。マイクロ波凝固を併用した 1 例は膀胱容量が 一時 $50 \mathrm{ml}$ と著明に減少したが, 3 力月後には $200 \mathrm{ml}$ ま でに増加した。なおこの症例は, 治療 1 年後, 壊死を 起こした膀胼壁に石灰化を生じ超音波切石術を施行し た．消化器症状，インポテンッなどはこれまでの観察 期間では認められていない。血液, 生化学検査値には 著明な变化は認められなかった。

\section{5. 考案}

中心部にラジゥムを設置したバルンカテーテルを膀 脱内で膨らませて行う腔内照射治療は Walter-Reed
法として Freedmann and Lewis ${ }^{7)}$ とって詳細に報 告されている。彼らの報告によれば線源付きバルンを 4 日間留置し, $5 \sim 7$ 日の間隔で $2 \sim 6$ 回の照射を行 5 と膀胱粘膜は $6,000 \sim 10,000 \mathrm{rads}$ の線量を照射され ることになり， 50 例の患者にこの治療を行い 5 年生存 率は56\%であったと述べている。また Hewitt ら゙'は55 例の表在性腫腸に対して線源付きのバルンカテーテル による腔内照射を行い $59 \%$ に有効で, 特に多発性表在 性腫瘍や carcinoma in situ に対しては良い方法であ ると述べている。

Russell $ら^{10)}$ は12例の膀胱癌に対し外照射法之膀胱 腔内照射を併用して行い短期間の観察ではあるが，9 例に有効であったと報告している。このように比較的 浸潤度の低い患者にとって腔内照射治療は有効である ことが報告されているが，いくつかの問題点を含んで いる，第 1 は医療スタッフや来訪者の被爆であり， Hewitt ら゙) は患者との接触を時間で制限したり, 距離 
を保つことが必要であると述べている，次の問題点は 治療に要する時間が長いことである. Hewitt ら6)は中 心線源にラジゥム, Russel ら ${ }^{10)}$ はCs を用いているが, いずれも今回私どもが使用した線源に比べ著しく線量 率が低いため $4,000 〜 5,000$ rads の照射を行らには 4 〜 5 日照射時間がかかり，この間患者は日常生活を制 限されることになる。

前述のような不都合を解決するために高線量率の線 源を用いた遠隔操作式後充填法による腔内照射治療法 が Henscheke ら ${ }^{11)}$, 若林ら ${ }^{12)}$, O'connel ら ${ }^{13)}$ にって 創案実用化された。現在，主として子宮頝癌，食道癌 に対して施行されその成績もいくつか報告されてい る. 今回私たちは膀胱腫瘍に対しても後充填式照射法 による治療が可能ではないかと考元，新しい膀脱鏡と loading tubeを試作した。

経膀脱鏡的局所照射法の最大の特徵は腫瘍に充分な 線量を与えることができることである。それは使用す るCo-60の放射線活性が従来の腔内照射に用いられた Ra などに比べると300〜1,000倍大きいこと，そして 腫瘍に非常に近接させた照射ができることによってい る。放射活性の大きな線源を用いることによって治療 時間が短縮でき，患者を隔離管理する必要もない，そ して本法は開創照射のような手術の必要はなく，日常 に行なっている膀胱鏡と同じ要領で施行できるので外 来治療も可能である.

本法では線源と照射部位とは非常に近接した照射で あるので, 線量分布の特性から隣接藏器や, 正常組織 への有害な被爆は少なく障害も起こり難いと考兄られ る.すなわち外照射にみられるような出血性膀脱炎, 排尿困難, 直腸炎, 皮膚炎, 陰萎などの副作用を軽減 できる点も特徴と言える。

さらに，本法では従来の腔内照射では避けることが できなかった術者拈よび医療スタッフの被爆を皆無に するこもができる点が特徵であろう.

以上のような特徵とは別に，本法によって腔内照射 を施行し，腫瘍を観察していると，その腫瘍の放射線 感受性を肉眼的に観察できる。すなわち本治療を施行 すると感受性の高い腫瘍ほど早く膀胼内の腫瘍は消失 するが，低いものは，変化も少ない。このことは再発 性腫瘍あるいは転移巣への照射治療の有効性をある程 度推定でき治療の参考となるであろう。

次に, これから解決しなければならないいくつかの 問題点について述べる，第一は，どのような膀胱腫痬 に本法が有効なのかを確認する必要がある，膀胱腫瘍
の約 $1 / 3 か ゙$ 放射線治療で有効と考号られていが, どの ような組織型, 発育形式の腫瘍に放射線感受性が高い のか，ぞのくらいの線量を照射すれば効果的なのか， また多少感受性の低い腫瘍であっても本法によって lethal dose 以上の照射を行学ば治癒を期待できるの かどうか，一期的照射がよいのか分割照射がよいのか 等について今後検討しなければならない。また本治療 法と従来から行われている治療法, 手術, 化学寮法, 外照射などとの併用効果についても検討しなければな らないであろら。

本治療後に, 腫瘍の異所性再発が10例中 3 例に認め

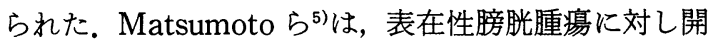
創照射を行うと有意に再発率は低くなったと述べ，そ の機序として免疫学的作用を推定している. 本治療法 はTURなどと同様に局所療法にとどあるのか，ある いは再発予防効果があるのかは現時点では不明であ り, 今後の検討を要する。

本法は外照射に比べ副作用は極めて少ないと予想さ れているが，放射線治療による障害は晚発性合併症が 問題となることが多い:今後本法による治療成績を上 げるためにも適正な照射線量の決定と副作用の面での 詳細な検討が必要である。

\section{結 語}

膀胱癌に対し Remote Afterloading System (RALS-20B)を用いた新しい経膀胼鏡的局所照射を紹 介した.

14例の膀胱癌患者に本治療を施行し，9例に CR を 得た.しかしこのらち 3 例は数カ月以内に異所性再発 を認めた。

この方法は, 腫瘍局所に充分な線量を照射可能で副 作用を軽減でき, 治療術者への放射線被爆量をなくす ことができた。

稿を終るにあたり，御指導を頂いた恩師土田正義教授に 深謝いたします。

\section{文献}

1) Miller, L.S.: Bladder cancer: Superiority of preoperative irradiation therapy and cystectomy in clinical stages $B_{2}$ and $C$. Cancer, 39, 973-980, 1977.

2) Goffinet, D.R., Schneider, M.J., Glastein, E.J., Ludwig, H., Ray, G.R., Punnick, N.R. and Bagshaw, M.A. : Bladder cancer : Results of radiation therapy in 384 patients. Therapeutic Radiology, 117, 148-149, 1975.

3) Van der Werf-Messing, B. and Hop, W.C.J. : 
Carcinoma of the urinary bladder (category $T_{1}$ $\mathrm{N}_{\mathrm{x}} \mathrm{M}_{\mathrm{o}}$ ) treated either by radium implant or by transurethral resection only. Int. J. Radiation Oncology Biol. Phys., 7, 299-303, 1981.

4) Matsumoto, K., Kakizoe, T., Miura, S., Tanaka, T., Knodo, I. and Umegaki, Y.: Clinical evaluation intraoperative radiotherapy for carcinoma of the urinary bladder. Cancer, 47, 509-513, 1981.

5) Walton, R.T. and Sinciair, W.K. : Radioactive solution ( $\mathrm{Na} 24$ and $\mathrm{Br} 82$ ) in the treatment of carcinoma of the bladder. Brit. Med. Bull., 8, 158-164, 1952.

6) Hewitt, C.B., Babiszewsky, J.F. and Antanez, A.R.: Update on intracavitary radiation in the treatment of bladder Cancer. J Urol., 126, $323-325,1981$.

7) Friedman, M. and Lewis, L.G. : Irradiation of carcinoma of the bladder by a central intracavitary radium or coblat-60 saurce (The Walter Reed Technique). Am. J. Roent., 79, 6-31, 1958.

8) Harada, T., Tsuchida, S., Nishizawa, O., Kigur- e, T. and Noto, H.: Transcystoscopic intravesical irradiation for urinary bladder cancer. J. Urol., 135, 186, 1986.

9）原田 忠：膀脱癌に対するマイクロ波凝固療法。 日本泌尿会誌，投稿中.

10) Russel, A.H., Marketle, K. and Tong, D.Y.: Intracavitary irradiation for carcinoma of the urinary daldder: Rationale technique and preliminary results. Int. J. Radiat. Oncol. Biol. Phys., 10, 215-219, 1984.

11) Henscheke, U.K., Hirlaris, B.S. and Mahan, G. D.: Remote afterloading with intracavitary applicators. Radiology, 83, 344-345, 1964.

12）若林 勝, 入江五郎, 菅原 正, 三橋英夫, 山口成 厚, 重茂 潔, 花島尚子, 加藤斉之, 松田正二, 乾 安行, 田近邦夫, 平山嘉明: 遠隔操作式 Afterloading装置の試作一Remote Afterloading system について。臨床放射線，11，678-684，1966.

13) O'Connel, D., Howard, N., Joslin, C.A.F., Ramsey, N.W. and Liversage, W.E.: A new remontely controlled unit for the treatment of uterine carcinoma. Lancet, 2, 570-571, 1965.

(1987年 4 月21日受理) 